\title{
The Review of Evolutionary Political Economy inaugural issue, part 2
}

\section{Silvano Cincotti ${ }^{1}$ - Wolfram Elsner ${ }^{2}$. Nathalie Lazaric ${ }^{3}$. Anastasia Nesvetailova ${ }^{4}$. Engelbert Stockhammer ${ }^{5}$}

(C) The Author(s) 2020

The present REPE issue 2-2020 is the second part of our inaugural "double pack". We were lucky to receive more papers for the inaugural issue than we could accommodate in one issue. So please enjoy another set of challenging original research papers gauging the field of evolutionary political economy.

In Financialisation and the periodisation of capitalism: appearances and processes, Jan Toporowski argues that the analysis of financial processes is essential for understanding changes in the financial system. Only these processes give rise to appearances such as the statistical data that are the basis of most studies of financialization. Those processes are fundamentally determined by the structure of the financial system. Following Minsky, Toporowski focuses on corporate finance which, through its effect on business investment, influences the dynamics of the capitalist system. As financial structures change, this gives rise to particular phases of capitalist development. The paper thus builds on Minsky's historical institutional analysis, but offers a more

Wolfram Elsner

welsner@uni-bremen.de

Silvano Cincotti

silvano.cincotti@unige.it

Nathalie Lazaric

nathalie.lazaric@gredeg.cnrs.fr

Anastasia Nesvetailova

Anastasia.Nesvetailova.1@ city.ac.uk

Engelbert Stockhammer

engelbert.stockhammer@kcl.ac.uk

1 University of Genoa, Genoa, Italy

2 University of Bremen, Bremen, Germany

3 Université Côte d'Azur, CNRS, Nice, France

4 City University London, London, UK

5 King's College London, London, UK 
systematic analysis. It offers a periodization of capitalism through mercantile capitalism, classic, bank-based capitalism, finance capital, state finance capitalism, to pension fund capitalism and capital market inflation. It shows how each period ends with financial difficulties that are overcome with financial innovation leading to a new financial structure with corresponding changes in financial processes. Specifically, the paper argues that the phase of capital market inflation, inaugurated by funded pension schemes in the last decades of the twentieth century, has come to an end in the illiquidity of capital markets that lies behind the 2008 financial crisis. The paper suggests that the measures of "unconventional monetary policy", or "Quantitative Easing", mark a new period of state finance capital with a return to the state support of a structurally illiquid capital market that already had prevailed in Europe and North America from the 1930 s to the 1960 s.

The discipline of International Political Economy - IPE — has been flirting with evolutionary approaches for the past decade or so. So far, attempts to develop a take on evolutionary theory have proceeded in a rather unstructured way: They range from potential applications of Darwinian theory of selection to more recent efforts to draw on ecological approaches and complexity theory when analysing crises and transformations. There has also been a renewed interest in institutionalist approaches and heterodox tradition, but this too, has been a fragmented process. Ronen Palan's article An Evolutionary Approach to International Political Economy: The Case of Corporate Tax Avoidance aims to offer a pathway to a more systemic framework of evolutionary political economy, in order to rethink the changes in the regulation on the contemporary system of states. Palan develops his approach by distinguishing between a tradition of political economy based on action of discreet entities (this reflects the roots of IPE in neoclassical economics) and a tradition of thought centred around a concept of transaction (taking root in original institutional economics). This framework opens up a new perspective on the traditional state-market dichotomy in IPE. One implication of such an approach has less to do with the conventional notion of captured governments or lack of political will, and more with the complex institutional terrain of the modern system of sovereignty. As Palan demonstrates, the core problem is that only a regulatory system can address the phenomenon of tax abuse and arbitrage; yet in the process, it is also likely to undermine the very institutional foundation of the market economy. So far, regulators have opted, unsurprisingly, for muddling along. The effect, however, has been that despite the increasing scope of the regulations, the fundamentals of ongoing tax and corporate abuse do not seem to change.

In Productivity and inequality in the UK: a political economy perspective, Philip Arestis argues that the development of labour productivity and income inequality are closely and significantly related. Productivity growth is the key determinant of how demand can grow without inflation, thereby reducing inequality of income, wealth and opportunity. In particular, a slowdown in productivity growth and an increase in inequality have occurred in the past decades and now affect many advanced economies, what has become more pronounced following the global financial crisis. Although weak productivity growth and increase in inequality predated this global financial crisis and the subsequent Great Recession, they have both been exacerbated. Focussing on the UK experience, Arestis analyses this from a Political Economy perspective, which emphasises the structure and power in an economic system.

Theo Papaioannou's article Reflections on the Entrepreneurial State, Innovation and Social Justice is also an invitation to reconsider social justice, inequality and 
redistribution, in this paper under technological innovation. The discussion starts with the famous debate about The Entrepreneurial State by Mariana Mazzucato, which emphasizes the limits of the liberal and neoliberal arguments. It is argued that the significance of long-term actions of the state is to take risks, to reduce uncertainty of agents and to design innovation differently. The idea of public risk-taking should not be divided from a political approach to the state. Justice and distribution of the benefits of innovation are critical and should be contextualized. While a more equal distribution of the benefits of technological innovation would reduce some inequality, it would not eliminate some forms of inequality such as discriminations based on colour, gender and castes present in many countries and often even reproduced with and within innovations (such as AI). Thus, if justice in innovation cannot be achieved through the implementation of redistributive policies, it must be rethought and re-implemented through new forms of governance, i.e. acting both on the distribution of benefits of innovation and on new forms of participation. Participation in the decision-making and new forms of legitimacy go beyond conventional redistributive policy but must include fairness as a key ingredient of designing innovative policies.

Frank Beckenbach, in the second part of his A value-theoretic approach to economic dynamics and evolution-synthesizing different Marxian modules in a simulation model, presents the simulation experiments on his novel evolutionary reconstruction of Marxian value theory and long-lingering transformation problem, theoretically and formally laid out in his part I in REPE issue 1. His novel reconstruction includes manuscripts of Marx that have become fully available only relatively recently through the progress of the international MEGA project, which are suggesting a valuetheoretic reconstruction of the main parts of Marx's critique of Political Economy. After a simulation run for a standard configuration (the "moderation regime"), the simulations integrate characteristics of the capitalist development as emphasized by Marx, such as the social conflict regime and the crisis regime. Solutions to longlingering theoretical problems can be solved only in such complex modelling and related simulations. A more consistent Marxist approach should be achieved this way.

Lynne Chester provides her analytical report The 2019-20 Australian bushfires: A potent mix of climate change, problematisation, Indigenous disregard, a fractured federation, volunteerism, social media and more. Intensity and duration of the 20192020 Australian bushfires have been unique, with unprecedented global impacts. We invited this paper for both these practical impacts and their theoretical implications. The area burnt was huge, it took seven months to contain or extinguish the fires, the smoke plume was the equivalent size of the eleven largest states of the USA, and carbon dioxide emissions have been enormous. More than a billion animals perished. The paper argues that the story of these bushfires is more complex than one of climate change, but includes a conjunction of cumulative events, (in)actions and institutions, a mix of the problematisation of bushfires and governing, a federation of nation and local states fractured by constitutional responsibilities, the impact of neoliberal austerity policies on land management, discordant local-state policies, a long-term disregard of Indigenous fire practices, the role of community (volunteerism), the transmission of (mis)information by social and traditional media, record temperatures, national rainfall the lowest for over a century, and a severe three-year drought. The entire plurality of critical economic perspectives is concerned and discussed in the article. 
Finally, we provide you with a book review of Marc Lavoie on Yoshinori Shiozawa et al.'s Microfoundations of Evolutionary Economics, which thematically lies at the heart of REPE's scope, but is to be critically reviewed, nevertheless.

In the future, we will prefer review articles over reviews of individual books. For this and all other relevant information on $R E P E$, including our current calls for papers and special issues, please visit our website:

https://www.springer.com/journal/43253.

With best wishes, and hope for an ever more intense collaboration with our readers in the future.

Funding Information Open Access funding provided by Projekt DEAL.

Open Access This article is licensed under a Creative Commons Attribution 4.0 International License, which permits use, sharing, adaptation, distribution and reproduction in any medium or format, as long as you give appropriate credit to the original author(s) and the source, provide a link to the Creative Commons licence, and indicate if changes were made. The images or other third party material in this article are included in the article's Creative Commons licence, unless indicated otherwise in a credit line to the material. If material is not included in the article's Creative Commons licence and your intended use is not permitted by statutory regulation or exceeds the permitted use, you will need to obtain permission directly from the copyright holder. To view a copy of this licence, visit http://creativecommons.org/licenses/by/4.0/. 